\title{
Perbedaan Profil Lipid pada Akseptor Depo Medroksi Progesteron Asetat dengan Implant Levonorgestrel di Wilayah Kerja Puskesmas Air Tawar Padang Tahun 2014
}

\author{
Rafika Oktova ${ }^{1}$, Desmiwarti ${ }^{2}$, Arni $\mathrm{Amir}^{3}$
}

\begin{abstract}
Abstrak
Depo Medroksiprogesteron Asetat dan Implant Levonorgestrel merupakan kontrasepsi hormonal progestin sintetik yang memiliki efek samping yaitu peningkatan berat badan dan mempengaruhi metabolisme lipid. Tujuan penelitian ini adalah untuk mengetahui perbedaan profil lipid pada akseptor Depo Medroksiprogesteron Asetat dengan Implant Levonorgestrel. Ini adalah studi observasional dengan desain cross sectional comparative. Penelitian dilakukan di laboratorium Bagian Biokimia Fakultas Universitas Andalas dari Maret sampai Mei 2014. Subjek penelitian terdiri dari dua kelompok, masing-masing 20 subjek. Pemeriksaan dengan metode enzimatis kolorimetri yaitu GPO-PAP untuk trigliserida, dan CHOD-PAP untuk kolesterol total, HDL dan LDL. Data dianalisis menggunakan uji $t$ dengan nilai p $<0.05$ dianggap bermakna secara statistik. Rerata kadar LDL pada Depo Medroksiprogesteron Asetat lebih tinggi $(95,51 \pm 20,47) \mathrm{mg} / \mathrm{dl}$ daripada Implant Levonorgestrel $(79,35 \pm 12,55) \mathrm{mg} / \mathrm{dl}$ dengan nilai $p<0,05$ artinya terdapat perbedaan yang bermakna sedangkan kadar trigliserida, kolesterol total dan HDL tidak bermakna. Kesimpulan penelitian in adalah terdapat perbedaan yang bermakna rerata kadar LDL pada Depo MedroksiprogesteronAsetat dan Implant Levonorgestrel, sedangkan kadar trigliserida, kolesterol total dan HDL tidak bermakna. Secara klinis profil lipid pada kedua kelompok dalam keadaan normal.
\end{abstract}

Kata kunci: profil lipid, depo medroksiprogesteron asetat, implant levonorgestrel

\begin{abstract}
Depo Medroxyprogesterone Acetate and Levonorgestrel Implants are synthetic progestine hormonal contraceptives that have side effect in body weight and lipid metabolism. The objective of this study was to determine the differences of lipid profile between acceptors Depo Medroxyprogesterone Acetate and Levonorgestrel Implants. This was a comparative cross sectional study. The study was done at laboratory of Biochemistry Departement in Medical Faculty of Andalas University from March until May 2014. The subjects were consisted of two groups, each group had 20 subjects. The examination used an enzymatic colorimetric method GPO-PAP for trygliserides and CHOD-PAP for total cholesterol, HDL and LDL. Data was analyzed using analysis of $t$-test with $p<0.05$ was considered to be significantly different. LDL levels average in Depo Medroxyprogesterone Acetate was $(95,51 \pm 20,47) \mathrm{mg} / \mathrm{dl}$ and Levonorgestrel Implants was $(79,35 \pm 12,55) \mathrm{mg} / \mathrm{dl}$ with $\mathrm{p}$-value, it means there is a significantly difference, but levels of trygliserides, total cholesterol and HDL means there is no significantly difference. This research concluded that there is a significant difference on average levels of LDL in the Depo Medroxyprogesterone Acetate and Levonorgestrel Implants but levels of trygliserides, total cholesterol and HDL there is no significantly difference. The clinically lipid profile in the two groups is in normal range.
\end{abstract}

Keywords: lipid profile, depo medroxyprogesterone acetate and levonorgestrel implants

Affiliasi penulis : 1. Program Studi Magister Kebidanan FK UNAND (Fakultas Kedokteran Universitas Andalas Padang), 2.
Bagian Kebidanan FK UNAND/RSUP Dr. M Djamil Padang, 3. Bagian Biologi FK UNAND

Korespondensi : Rafika Oktova, E-mail: rafikamkeb@gmail.com, Telp: 085364273030 


\section{PENDAHULUAN}

Depo Medroksiprogesteron Asetat (DMPA) dan Implant Levonorgestrel (LNG) merupakan kontrasepsi hormonal progestin sintetik yang saat ini paling sering digunakan. Kedua jenis kontrasepsi ini memiliki efek samping yaitu peningkatan berat badan dan perubahan metabolisme lipid pada penggunaan jangka panjang. Berdasarkan studi internasional bahwa sekitar 35\% akseptor DMPA dan LNG menghentikan penggunaan pada satu tahun pertama dan $50 \%$ pada dua tahun penggunaan. Alasan medis menghentikan adalah karena terjadi peningkatan berat badan. ${ }^{1,2}$

Implant LNG merupakan turunan testosteron yang memiliki efek mineralokortikoid yang mempengaruhi mineral cairan ekstraseluler sedangkan DMPA merupakan progesteron sintetik yang susunan kimianya menyerupai progesteron yang memiliki sifat glukokortikoid yang mempengaruhi metabolisme lemakserta menurunkan sekresi insulin sehingga kedua jenis kontrasepsi ini dapat menyebabkan peningkatan berat badan. ${ }^{3}$

Berenson dan Rahman di tahun 2010, pada penelitiannya di Texas dengan 240 subjek penggunaan DMPA diperoleh peningkatan berat badan selama penggunaan 6 bulan (1,5 kg), 12 bulan (1,9 kg), 18 bulan (4,4 kg), 24 bulan (4,5 kg), 30 bulan $(4,9 \mathrm{~kg})$ dan 36 bulan $(5,1 \mathrm{~kg}) .{ }^{4}$ Laphikanont W (2006), penelitian di Thailand pada 59 subjek penggunaan implant LNG selama 6 bulan diperoleh peningkatan berat badan $(1,4 \mathrm{~kg}){ }^{5}$

Penelitian Balogun pada tahun 2006 di Nigeria tentang analisis berat badan pada pengunaan Implant Levonorgestrel diperoleh peningkatan berat badan pada penggunaan selama 6 bulan $(1,3 \mathrm{~kg})$ dan penggunaan 12 bulan $(2,4 \mathrm{~kg}){ }^{6}$ Menurut Sivin $d k k l$ di tahun 2002 studi surveilans di China diperoleh peningkatan berat badan $(2,5 \mathrm{~kg})$ selama penggunaan 5 tahun Implant Levonorgestrel. ${ }^{7}$

Yadav dkk di tahun 2011, pada penelitiannya tentang pengaruh penggunaan jangka panjang dari DMPA terhadap metabolisme lipid pada 60 wanita di Nepal yang telah menggunakan lebih dari 2 tahun menunjukkan bahwa kadar trigliserida, kolesterol total dan Low Density Lipoprotein (LDL) lebih tinggi daripada non akseptor, sedangkan kadar High Density
Lipoprotein (HDL) menurun. Adanya hal tersebut maka dapat disimpulkan DMPA dapat menyebabkan perubahan metabolisme lipid yang dapat meningkatkan resiko penyakit kardiovaskular (penyakit jantung) ${ }^{8}$

Perubahan metabolisme lemak terjadi karena adanya pengaruh hormonal progesteron sehingga menyebabkan gangguan keseimbangan profil lipid dalam tubuh. Terjadinya perubahan profil lipid (trgliserida, kolesterol total, HDL dan LDL) serum pada penggunaan jangka panjang DMPA dan LNG menjadi faktor resiko penyakit aterosklerosis (penumpukan lemak di dinding arteri) dan kardiovakular. ${ }^{9}$

Peningkatan kadar trigliserida, kolesterol total, LDL dan penurunan HDL serta peningkatan berat badan berlebih merupakan kriteria diagnosis sindrom metabolik yang dapat meningkatkan terjadinya diabetes mellitus tipe II dan kardiovaskular. Oleh sebab itu, profil lipid merupakan prediktor terbaik untuk mengetahui sindrom metabolik. ${ }^{10}$

Tujuan penelitian ini adalah untuk mengetahui perbedaan profil lipid pada akseptor DMPA dan LNG.

\section{METODE}

Penelitian ini adalah observasional dengan desain cross sectional comparative. Pemeriksaan profil lipid dilakukan di laboratorium Bagian Biokimia Fakultas Universitas Andalas pada dari Maret sampai dengan Mei 2014. Populasi penelitian ini adalah semua akseptor DMPA dan LNG di Wilayah Kerja Puskesmas Air Tawar Padang. Subjek penelitian yang dipilih adalah semua populasi yang memenuhi kriteria inklusi dan eksklusi. Kriteria inklusi adalah penggunaan kontrasepsi secara terus menerus $>2$ tahun, umur 20-35 tahun, Indek Massa Tubuh (IMT) sebelum penggunaan kontrasepsi normal (18,5-24,9 $\mathrm{kg} / \mathrm{m}^{2}$ ), tercatat pada buku status pasien/kartu KB. Kriteria eksklusi adalah perokok berat (>15 batang/hari), menggunakan obat penurun berat badan, melakukan olahraga rutin minimal 30 menit setiap hari, riwayat penyakit (diabetes mellitus, jantung, hipertensi dan obesitas)

$$
\text { Jumlah subjek dihitung dengan }
$$

menggunakan rumus uji hipotesis terhadap rerata dua populasi independen. ${ }^{11}$ Berdasarkan rumus tersebut, 
diperoleh jumlah subjek sebesar 17 orang, ditambah drop out $15 \%$ menjadi 20 orang.

$$
\begin{aligned}
& \mathrm{n}_{1}=\mathrm{n}_{2}=2(\mathrm{Z \alpha}+\mathrm{Z} \beta) \mathrm{S}^{2} \\
& \left(\mathrm{X}_{1}-\mathrm{X}_{2}\right)
\end{aligned}
$$

Keterangan :

$$
\begin{array}{ll}
\mathrm{n} & =\text { besar sampel } \\
\mathrm{x}_{1}-\mathrm{x}_{2} & =\text { perbedaan klinis yang diinginkan } 3,1 \\
\mathrm{Z}_{\alpha} & =\text { tingkat kemaknaan }(\alpha=5 \%=1,96) \\
\mathrm{Z}_{\beta} & =\text { power penelitian }(\beta=10 \%=1,282) \\
\mathrm{S} & =\text { standar deviasi } 2,5 .{ }^{12}
\end{array}
$$

Metode pengambilan sampel adalah multistage simple random sampling. Pemeriksaan profil lipid dengan metode enzimatis kolorimetri yaitu (GPO-PAP = Glycerol Phospat Oxidase-Phenol Aminoantypirine) untuk trigliserida dan (CHOD$\mathrm{PAP}=$ Cholesterol Oxidase - Phenol Aminoantypirine) untuk kolesterol total, HDL dan LDL.

Data terlebih dahulu diuji normalitas dengan uji kolmogorov-smirnov, maka diperoleh data berdistribusi normal (nilai $0>$ 0,05). Kemudian dilanjutkan uji $t$ tidak berpasangan. Perbedaan bermakna secara statistik apabila nilai $p<0,05$.

\section{HASIL}

Penelitian ini telah dilakukan terhadap 40 responden yang memenuhi kriteria inklusi dan eksklusi terdiri dari dua kelompok yaitu 20 akseptor DMPA dan 20 akseptor Implant LNG.

Tabel 1. Karakteristik Responden Penelitian

\begin{tabular}{lccc}
\hline Karakteristik & $\begin{array}{c}\text { DMPA } \\
(\mathbf{n}=20)\end{array}$ & $\begin{array}{c}\text { Implant LNG } \\
(\mathbf{n}=20)\end{array}$ & $\boldsymbol{p}$ \\
\cline { 2 - 3 } & $\begin{array}{c}\text { Mean } \pm \text { SD } \\
\text { (tahun) }\end{array}$ & $\begin{array}{c}\text { Mean } \pm \text { SD } \\
\text { (tahun) }\end{array}$ & \\
\hline Umur & $30,95 \pm 4,31$ & $32,40 \pm 4,22$ & 0,289 \\
& & & \\
\hline
\end{tabular}

Tabel 1 menunjukkan rerata umur responden yang menggunaka DMPA yaitu $(30,95 \pm 4,31)$ tahun dan Implant LNG yaitu $(32,40 \pm 4,22)$ tahun. Hasil uji t menunjukkan bahwa nilai $p=0,289(p>0,05)$. Hal ini berarti secara statistik tidak ada perbedaan yang bermakna antara kedua kelompok.

Tabel 2. Peningkatan Berat Badan Responden

\begin{tabular}{cccc}
\hline & DMPA & Implant LNG & $p$ \\
& $(\mathbf{n = 2 0})$ & $(\mathbf{n = 2 0})$ & \\
\cline { 2 - 3 } & Mean \pm SD & Mean \pm SD & \\
& $(\mathbf{k g})$ & $\mathbf{( k g )}$ & \\
\hline Berat Badan & $10,15 \pm 6,57$ & $9,90 \pm 7,48$ & 0,911
\end{tabular}

Tabel 2 menunjukkan rerata peningkatan berat badan responden selama pemakaian $>2$ tahun DMPA yaitu $(10,15 \pm 6,57) \mathrm{kg}$ dan Implant LNG yaitu $(9,90 \pm 7,48) \mathrm{kg}$. Hasil uji t menunjukkan nilai $p=0,911$ $(p>0,05)$. Hal ini berarti secara statistik tidak ada perbedaan yang bermakna antara kedua kelompok.

Tabel 3. Perbedaan Rerata Kadar Trigliserida Serum Pada Akseptor DMPA dan LNG

\begin{tabular}{lcc}
\hline $\begin{array}{c}\text { Jenis } \\
\text { Kontrasepsi }\end{array}$ & $\begin{array}{c}\text { Kadar Trigliserida Serum } \\
\text { Rerata } \pm \text { SD } \\
(\mathbf{m g} / \mathbf{d l})\end{array}$ & $\boldsymbol{p}$ \\
\hline DMPA & $133,02 \pm 29,53$ & \\
Implant LNG & $121,31 \pm 24,06$ & 0,177 \\
\hline
\end{tabular}

Tabel 3 menunjukkan bahwa rerata kadar trigliserida pada akseptor DMPA lebih tinggi yaitu $(133,02 \pm 29,53) \mathrm{mg} / \mathrm{dl}$ daripada Implant LNG yaitu $(121,31 \pm 24,06) \mathrm{mg} / \mathrm{dl}$. Hasil uji $\mathrm{t}$ diperoleh nilai $\mathrm{p}=$ $0,177$ ( $p>0,05)$. Hal ini berarti secara statistik tidak ada perbedaan yang bermakna antara kedua kelompok.

Tabel 4. Perbedaan Rerata Kadar Kolesterol total Serum Pada Akseptor DMPA dan LNG

\begin{tabular}{lcc}
\hline $\begin{array}{c}\text { Jenis } \\
\text { Kontrasepsi }\end{array}$ & $\begin{array}{c}\text { Kadar Kolesterol total serum } \\
\text { Rerata } \pm \text { SD } \\
(\mathbf{m g} / \mathbf{d l})\end{array}$ & $\boldsymbol{p}$ \\
\hline DMPA & $171,33 \pm 35,61$ & 0,728 \\
Implant LNG & $175,58 \pm 41,17$ & \\
\hline
\end{tabular}

Tabel 4 menunjukkan bahwa rerata kadar kolesterol total pada akseptor Implant LNG lebih tinggi yaitu $(175,58 \pm 41,17) \mathrm{mg} /$ dldaripada DMPA yaitu $(171,33 \pm 35,61) \mathrm{mg} / \mathrm{dl}$. Hasil uji t diperoleh nilai $\mathrm{p}=$ $0,728$ ( $p>0,05)$. Hal ini berarti secara statistik tidak ada perbedaan yang bermakna antara kedua kelompok. 
Tabel 5. Perbedaan Rerata Kadar HDL Serum Pada Akseptor DMPA dan LNG

\begin{tabular}{lcc}
\hline $\begin{array}{c}\text { Jenis } \\
\text { Kontrasepsi }\end{array}$ & $\begin{array}{c}\text { Kadar HDL Serum } \\
\text { Rerata } \pm \text { SD } \\
(\mathbf{m g} / \mathbf{d l})\end{array}$ & $\boldsymbol{p}$ \\
\hline DMPA & $75,81 \pm 34,84$ & \\
Implant LNG & $96,23 \pm 43,32$ & 0,109 \\
\hline
\end{tabular}

Tabel 5 menunjukkan rata-rata kadar HDL pada akseptor DMPA yaitu $(75,81 \pm 34,84) \mathrm{mg} / \mathrm{dl}$ daripada Implant LNG yaitu $(96,23 \pm 43,32) \mathrm{mg} / \mathrm{dl}$. Hasil uji t didapatkan nilai $p=0,109(p>0,05)$. Hal ini berarti secara statistik tidak ada perbedaan yang bermakna antara kedua kelompok.

Tabel 6. Perbedaan Rerata Kadar LDL Serum Pada Akseptor DMPA dan LNG

\begin{tabular}{lcc}
\hline $\begin{array}{c}\text { Jenis } \\
\text { Kontrasepsi }\end{array}$ & $\begin{array}{c}\text { Kadar LDL Serum } \\
\text { Rerata } \pm \text { SD } \\
(\mathbf{m g} / \mathbf{d l})\end{array}$ & $\boldsymbol{p}$ \\
\hline DMPA & $95,51 \pm 20,47$ & \\
Implant LNG & $79,35 \pm 12,55$ & 0,005 \\
\hline
\end{tabular}

Tabel 6 menunjukkan reata kadar LDL pada akseptor DMPA lebih tinggi yaitu $(95,51 \pm 20,47) \mathrm{mg} / \mathrm{dl}$ daripada Implant LNG yaitu $(79,35 \pm 12,55) \mathrm{mg} / \mathrm{dl}$. Hasil uji t didapatkan nilai $p=0,005(p<0,05)$. Hal ini berarti secara statistik terdapat perbedaan yang bermakna antara kedua kelompok.

\section{PEMBAHASAN}

Pada penelitian ini diperoleh kadar trigliserida, LDL lebih tinggi dan kadar HDL lebih rendah pada Depo Medroksiprogesteron Asetat daripada Implant Levonorgestrel. Hal ini disebabkan oleh efek metabolik dari Depo Medroksiprogesteron Asetat yaitu sama dengan hormon glukokortikoid yaitu meningkatkan lipolisis (pemecahan trigliserida di jaringan adipose menjadi asam lemak bebas) dan menurunkan sekresi insulin. Sedangkan Implant Levonorgestrel memiliki efek yang sama dengan hormon mineralokortikoid yaitu mempengaruhi keseimbangan air dan elektrolit serta kurang mempengaruhi metabolisme lemak. Walaupun kadar trigliserida, LDL lebih tinggi dan HDL lebih rendah pada Depo Medroksiprogesteron Asetat, tetapi secara klinis kadar trigliserida, LDL dan HDL masih dalam batas normal.

Efek glukokortikoid Depo Medroksi progesteron Asetat adalah meningkatkan sekresi Neuropeptida Y (NPY) yaitu suatu peptida di hipotalamus yang menurunkan sekresi hormon leptin (derivat sel lemak yang mempengaruhi NPY) dan insulin sehingga akan meningkatkan nafsu makan. Peningkatan nafsu makan akan meningkatkan asupan makanan dan berat badan. ${ }^{13}$ Peningkatan nafsu makan secara temporal atau permanen dapat menyebabkan penambahan berat badan dan obesitas. $^{14}$

Berat badan berlebih atau obesitas mempunyai depot lemak berupa trilgiserida dalam jumlah banyak sehingga pada waktu terjadi hidrolisis/lipolisis trigliserida di jaringan adiposa menghasilkan asam lemak bebas (Free Fatty Acids/FFA) dalam jumlah yang lebih banyak. Asam lemak bebas dalam jumlah banyak dibawa ke hati untuk bahan baku pembentukan trigliserida, sehingga menyebabkan meningkatnya sintesis trigliserida yaitu pembentukan trigliserida dari asam lemak bebas (reesterifikasi). Peningkatan sintesis trigliserida di hati akan meningkatkan penyimpanan trigliserida yang menyebabkan peningkatan sekresi Very Low Desnity Lipoprotein (VLDL), sehingga VLDL masuk ke sirkulasi darah. Peningkatan VLDL di sirkulasi menyebabkan terjadinya peningkatan trigliserida dalam darah (hypertrigliseridemia), karena VLDL membawa trigliserida dari hati ke sirkulasi darah. ${ }^{15,16}$

Peningkatan lipolisis akan terjadi peningkatan

FFA. Peningkatan FFA pada obesitas akan menyebabkan terjadinya resistensi insulin. Resistensi insulin akan mengaktivasi Apo (Apoprotein) CIII yang berperan menurunkan kerja lipoprotein lipase dan mengaktivasi Apo B100 yang berperan dalam meningkatkan sekresi VLDL di hati, sehingga akan membawa trigliserida ke dalam sirkulasi, akibatnya trigliserida dalam sirkulasi akan meningkat. Peningkatan trigliserida di sirkulasi akibat resistensi insulin akan menimbulkan keadaan hypertrigliseridemia. Pada keadaan resistensi insulin VLDL meningkat dalam sirkulasi dan akan meningkatkan LDL karena sebagian besar LDL 
terbentuk dari VLDL. ${ }^{17,18}$

Keadaan hypertrigliseridemia terjadi akibat dari peningkatan lipolisis trigliserida di jaringan adiposa, sehingga menyebabkan peningkatan FFA di sirkulasi yang kemudian dibawa ke hati untuk sintesis trigliserida. Peningkatan sintesis trigliserida mengakibatkan meningkatnya sekresi VLDL. VLDL dari hati membawa trigliserida ke sirkulasi dan menyebabkan peningkatan LDL dalam darah serta penurunan kadar HDL. ${ }^{19}$ Oleh sebab itu, pada pemeriksaan kadar trigliserida, LDL serum pada Depo Medroksiprogesteron Asetat lebih tinggi dan lebih rendah kadar HDL daripada Implant Levonorgestrel.

Penelitian ini sejalan dengan penelitian Okeke et al (2011) di Nigeria pada 26 akseptor juga menunjukkan hasil yang sama yaitu rerata kadar trigliserida pada akseptor Depo Medroksiprogesteron Asetat lebih tinggi yaitu $(102,35 \pm 11,57) \mathrm{mg} / \mathrm{dl}$ daripada non-akseptor yaitu $(82,77 \pm 2,67) \mathrm{mg} / \mathrm{dl}$ dengan nilai $p>0,05 .^{20}$ Hasil penelitian yang sama juga dilakukan oleh Youzbaki (2011) di Irak pada 30 akseptor juga menunjukkan hasil bahwa rerata kadar trigliserida pada akseptor Depo Medroksiprogesteron Asetat lebih tinggi yaitu $(170,26 \pm 58,74) \mathrm{mg} / \mathrm{dl}$ daripada non-akseptor yaitu $(147,74 \pm 74,76) \mathrm{mg} / \mathrm{dl}$ dengan nilai $p=0,226(p>0,05)$, artinya tidak terdapat perbedaan yang bermakna secara statistik pada kedua kelompok. ${ }^{21}$

Hasil penelitian ini sama dengan penelitian yang dilakukan oleh Jamil et al (2012) di Pakistan menunjukkan rerata kadar LDL pada akseptor Depo Medroksiprogesteron Asetat $(88,79 \pm 7,40) \mathrm{mg} / \mathrm{dl}$ dibandingkan dengan akseptor Implant Levonorgestrel $(86,25 \pm 3,09) \mathrm{mg} / \mathrm{dl}^{22}$ Penelitian Mostafavi $d k k$ pada atahun 1999 di Iran menunjukkan bahwa rerata kadar LDL pada akseptor Depo Medroksiprogesteron Asetat $(106,86 \pm 29,64) \mathrm{mg} / \mathrm{dl}$ dan pada akseptor Implant Levonorgestrel $(93,60 \pm 28,08) \mathrm{mg} / \mathrm{dl}$ dengan nilai $p<0,05$ (0,001), artinya terdapat perbedaan yang bermakna secara statistik pada kedua kelompok. ${ }^{23}$

Penelitian yang dilakukan pada tahun 2011 oleh Yadav dkk di Nepal yang menunjukkan rerata kadar HDL pada akseptor Depo Medroksiprogesteron Asetat lebih rendah yaitu $(42,51 \pm 24,96) \mathrm{mg} / \mathrm{dl}$ daripada non-akseptor $(44,46 \pm 5,85) \mathrm{mg} / \mathrm{dl}$ dengan nilai $p>0,05(0,626){ }^{8}$ Hasil penelitian yang sama juga dilakukan oleh Dasuki dkk di tahun 2008 menunjukkan rerata kadar HDL pada akseptor Depo Medroksiprogesteron Asetat lebih rendah yaitu $(61,16$ $\pm 15,69) \mathrm{mg} / \mathrm{dl}$ daripada non-akseptor $(80,32 \pm 15,05)$ mg/dl dengan nilai $p>0,05(0,821)$, artinya secara statistik tidak terdapat perbedaan yang bermakna pada kedua kelompok. ${ }^{24}$

Hasil penelitian ini diperoleh kadar trigliserida, LDL lebih tinggi dan lebih rendah kadar HDL pada Depo Medroksiprogesteron Asetat. Hal ini disebabkan oleh rerata peningkatan berat badan akseptor selama pemakaian >2 tahun Depo Medroksiprogesteron Asetat yaitu $(10,15 \pm 6,57) \mathrm{kg}$ dan Implant Levonorgestrel (9,90 $\pm 7,48) \mathrm{kg}$. Peningkatan berat badan merupakan salah satu penyebab terjadinya peningkatan kadar trigliserida, LDL dan penurunan HDL.

Pada penelitian ini rerata kadar kolesterol total pada Implant Levonorgestrel lebih tinggi daripada Depo Medroksiprogesteron Asetat. Sedangkan rerata kadar LDL pada Depo Medroksiprogesteron Asetat lebih tinggi daripada Implant Levonorgestrel. Hal ini tidak sesuai dengan kepustakaan yang ada bahwa apabila kadar LDL meningkat maka kolesterol total juga akan meningkat, karena sebagian besar kolesterol dibawa oleh LDL yaitu sekitar 60-70\% kolesterol diangkut oleh LDL dan sebagian kecil diangkut oleh HDL yaitu sekitar 15-25\%. ${ }^{17,25}$ Apabila kadar LDL meningkat pada Depo Medroksiprogesteron Asetat, maka kadar kolesterol total juga akan meningkat.

Berdasarkan tujuan penelitian ini yang untuk melihat perbedaan rerata kadar kolesterol total pada akseptor Depo Medroksiprogesteron Asetat dengan Implant Levonorgestrel saja. Depo Medroksi progesteron Asetat dan Implant Levonorgestrel merupakan turunan kolesterol, sehingga saling mempengaruhi kolesterol total.

Prekursor hormon steroid progesteron adalah kolesterol, artinya Depo Medroksiprogesteron Asetat dan Implant Levonorgestrel merupakan golongan hormon steroid yaitu progesteron yang disintesis dari kolesterol. Oleh sebab itu, kedua jenis kontrasepsi ini saling mempengaruhi kadar kolesterol total. ${ }^{17,25}$ Walaupun rerata kadar kolesterol total pada akseptor Implant Levonorgestrel lebih tinggi daripada Depo 
Medroksiprogesteron Asetat tetapi masih dalam batas normal (<200 mg/dl).

Hasil penelitian ini diperoleh tidak terdapat perbedaan rerata kadar trigliserida, kolesterol total dan HDL yang bermakna antara kedua kelompok. Terdapat perbedaan rerata kadar LDL yang bermakna secara statistik. Walaupun demikian, secara klinis kadar profil lipid masih dalam batas normal. Hal ini berarti bahwa banyak faktor yang mempengaruhi profil lipid yaitu umur. Umur responden pada penelitian ini dibatasi 20-35 tahun dengan rerata umur responden Depo Medroksiprogesteron Asetat 30,95 tahun dan rerata umur responden Implant Levonorgestrel 32,40 tahun sehingga tidak mempengaruhi kadar profil lipid (trigliserida, kolesterol total, HDL dan LDL).

Hal ini sesuai dengan penelitian Liputo $d k k$ di tahun 2010, bahwa umur mempunyai hubungan yang bermakna dengan kadar profil lipid. Kelompok umur $\geq$ 40 tahun mempunyai rerata kadar profil lipid (trigliserida, kolesterol total dan LDL) yang tinggi serta HDL yang rendah dibandingkan dengan kelompok umur $<40$ tahun. ${ }^{26}$

Keterbatasan dari penelitian ini adalah tidak dilakukannya pengukuran pada intake (asupan makanan) responden yang dapat mempengaruhi kadarprofil lipid. Faktor asupan makanan dan lingkungan juga dapat mempengaruhi kadar profil lipid. Penelitian ini dilakukan di daerah pantai yaitu di Air tawar Padang, yang berpotensial lebih banyak dan mudah mendapatkan ikan laut, dimana padaikan laut terdapat omega 3 yang dapat menurunkan kadar trigliserida, kolesterol total, LDL dan meningkatkan HDL.

Hal ini sesuai dengan penelitian LIPI pada tahun 2009, bahwa pada ikan laut seperti : tenggiri, kakap, kembung dan tuna banyak mengandung omega 3, yaitu suatu asam lemak tidak jenuh ganda yang mengandung asam EPA (Eicosapentaenoic) dan DHA (Decosahexaenoic) dimana Omega 3 dapat membantu menurunkan kadar trigliserida, kolesterol total, LDL dan meningkatkan HDL. ${ }^{27}$

Hal yang sama juga dikemukakan oleh Castle et al (2010), bahwa asam lemak tidak jenuh omega 3 yang mengandung EPA dan DHA banyak terdapat pada ikan laut seperti ikan salmon, tuna, sardine dan tongkol. Omega 3 dapat menurunkan kadar trigliserida, kolesterol total dan LDL serta meningkatkan kadar HDL. ${ }^{28}$

\section{KESIMPULAN}

Tidak terdapat perbedaan yang bermakna secara statistik rerata kadar trigliserida, kolesterol total dan HDL pada akseptor Depo Medroksiprogesteron Asetat dengan Implant Levonorgestrel. Terdapat perbedaan yang bermakna secara statistik rerata kadar LDL pada akseptor Depo Medroksiprogesteron Asetat dengan Implant Levonorgestrel, tetapi secara klinis kadar profil lipid pada kedua kelompok masih dalam batas normal.

\section{UCAPAN TERIMA KASIH}

Penulis mengucapkan terima kasih kepada Puskesmas Air Tawar Padang sebagai tempat penelitian atas fasilitas yang telah diberikan. Kepada dr. Desmiwarti, SpOG(K) dan Dra. Arni Amir, MS, sebagai pembimbing atas masukan dan bimbingan dalam menyelesaikan tesis ini.

\section{DAFTAR PUSTAKA}

1. Saifuddin $A B$. Buku panduan praktis pelayanan kontrasepsi. Jakarta: Yayasan Bina Pustaka Sarwono Prawirohardjo; 2006.

2. Speroff L, Robert HG, Nathan GK. Clinical gynecologic endocrinology and infertility: chapter 3 : long-acting methods of contraception. Edisi ke-6. New York: Lippincott Williams \& Wilkins; 2005.

3. Baziad A. Endokrinologi ginekologi Edisi ke-3. Jakarta: Media Aesculapius; 2008.

4. Berenson $A B$, Rahman M. Changes in weight, total fat, percent body fat, and central-toperipheral fat ratio associated with injectable and oral contraceptive use. Texas: University of Texas Medical Branch, Galveston; 2010. (diunduh 3 Oktober 2013). Tersedia dari: URL: HYPERLINK http://www.ncbi.nlm.nih.gov/pmc

5. Laphikanont W, Surasak TMD. Effects of Jadelle used in thai women aged between 20 and 45 years in King Chulalongkorn Memorial Hospital, Departemen Of Obstetrics and Gynecology Chulalongkorn University Thailand. 2006. (diunduh 5 Oktober 2013). Tersedia dari: URL: HYPERLINK http://www.medassocthai.org/journal 
6. Balogun OR. Analysis of weight, packed cell volume changes and menstrual pattern in norplant implant accepptors in llorin Nigeria, Departemen of Obstetrics and Gynaecoloy University of Ilorin Nigeria; 2006. (diunduh 5 Oktober 2013). Tersedia dari: URL: HYPERLINK http://www.ncbi.nlm.nih. gov/pubmed/17902502

7. Sivin I, Harold N, Sandra W. Jadelle levonorgestrel rod implants: a summary of scientic data and lessons learned from programmatic experience. New York: Population Council; 2002.

8. Yadav BK, et al. Effects of long-term use of depomedroxyprogesterone acetate on lipid metabolism in Nepalese Women. Institute of Medicine Tribhuvan University Teaching Hospital Nepal. 2011. (diunduh 3 Oktober 2013). Tersedia dari: URL: HYPERLINK http://www.kilm.org/pubmed centralcanada/3116007

9. Ridker PM, Genest J. Risk factor for artherosclerotic disease, hearth disease: a textbook of cardiovascular medicine. Edisi ke-6. WB Saunders; 2001.

10. Adult Treatment Panel (ATP) II. The national cholesterol education program (NCEP); 2002.

11. Sastroasmoro S. Dasar-dasar metodologi penelitian klinis, Edisi ke-4. Jakarta: CV Sagung Seto; 2011.

12. Faddah LM, Al-Rehany MA, Abdel H, Bakeet AA. Oxidative stress, lipid profile and liver functions in average Egyptian long term depo medroxyprogesterone acetate (DMPA) user. Faculty of Pharmacy and Faculty of Medicine Elminia Universty Egypt. 2005; 10 (diunduh 5 Oktober 2013). Tersedia dari: URL: HYPERLINK http://www.ncbi.nlm.nih.gov/pubmed/18007380

13. Meutia N. Peran neuropeptida $Y$ dalam meningkatkan nafsu makan. Jurnal Fisiologi. 2005; 11-1.

14. Isselbacher KJ. Harrison: prinsip-prinsip ilmu penyakit dalam Volume 3. Edisi ke-13. Jakarta: EGC; 2000.

15. Adam J. Dislipidemia, Buku Ajar IImu Penyakit Dalam Jilid III. Edisi ke-4. Jakarta: Pusat Penerbitan IImu Penyakit Dalam Fakultas Kedokteran Universitas Indonesia; 2007.
16. Jung UJ, Myung SC. Obesity and Its metabolic complications: the role of adinopektines and the relationship between obesity, inflammation, insulin resistance,dyslipidemia and nonalcoholic fatty liver disease. 2014. (diunduh 15 Juli 2014). Tersedia dari: URL: HYPERLINK http://www.mdpi. com/journal/iims

17. Mayes PA, Kathleen MB. Biokimia Harper: metabolisme asilgliserol dan sfingolipid; pengangkutan dan penyimpanan lipid; pengangkutan dan ekskresi kolesterol. Edisi ke-27. Jakarta: EGC: 2012. hlm.249-225.

18. Eckel RH. The Complex metabolic mechanism relating obesity to hypertriglyceridemia, division of endocrinology university of Colorado. 2011. (diunduh 15 Juli 2014). Tersedia dari: URL HYPERLINK http://atvb.aha.journals.org

19. Miller $\mathrm{M}$, et al. Triglycerides and cardiovascular disease: a scientific statement from the American Hearth Association. 2011. (diunduh 17 Juli 2014). Tersedia dari: URL: HYPERLINK http://www.circ.ahajournals.org

20. Okeke CU, et al. Comparative effects of injectable and oral hormonal contraceptives on lipid profile, department of Biochemistry Madonna University Elele Nigeria. 2011; 2(3): 21-20. (diunduh 4 Juli 2014). Tersedia dari: URL: HYPERLINK http://www.healthcare-bulletin.com

21. Youzbaki WB. C-reactive protein and lipid profile among depo medroxyprogesterone acetate injections users, College of Medicine University of Mosul Irak. 2011; 37(1,2); 56-48. (diunduh 5 Oktober 2013). Tersedia dari: URL: HYPERLINK http://www.iasj.net

22. Jamil S, Afshan S. Comparison of CVD risk associatd with the long term use of contraceptives in young females, departmen of pharmacology jinnah university for women pakistan. 2012; 2(2): 66-62. (diunduh 5 Oktober 2013). Tersedia dari: URL: HYPERLINK http://www.japsonline.com

23. Mostafavi $H$, Khadijeh A, Najaf Z. a comparative analysis of three metods of contraception: effects on blood glucose and serum lipid profiles, Shiraz University of Medical Sciences, Iran. 1999; 19(1): 11-8. (diunduh 5 Oktober 2013). Tersedia dari: 
URL;.HIPERLINK http://www.researchgate.net

24. Dasuki D, Olga S, Flourisa JS, Enny SP. Effect of hormonal contraception planibuß versus depo progestine ${ }^{\circledR}$ on liver function and lipid profile. Berita Kedokteran Masyarakat.2008;24(3):56-61.

25. Mayes PA. Biokimia Harper: metabolisme asilgliserol dan sfingolipid; pengangkutan dan penyimpanan lipid; sintesis, pengangkutan dan ekskresi kolesterol. Edisi ke-25. Jakarta: EGC: 2003. hlm. 281-45.
26. Liputo I, Fasli J, Helmizer. hubungan tingkat konsumsi antioksidan dengan profil lipid darah orang dewasa etnis Minangkabau di kota Padang. Majalah Kedokteran Indonesia. 2010;60(8);363-56.

27. LIPI. Kolesterol. Jakarta: UPT-Balai Informasi Teknologi LIPI; 2009.

28. Castle FLD, Paula RG. Omega 3 and omega 6 fatty acids. 2010. (diunduh 16 Mei 2014). Tersedia dari: URL: HYPERLINK http:// www.ianrpubs.unl. edu/live/g2032 